\title{
5 .レトロウイルスベクターによる遺伝子治療
}

\author{
塙秀 樹, 島 田隆
}

\section{はじめに}

レトロウイルスベクターはレトロウイルスに属するオン コウイルス，レンチウイルスなどを基に遺伝子組み換え技 術により作られたべクターの総称である（図1）。アデノ ウイルスやアデノ随伴ウイルスを基にしたベクターでは導 入遺伝子が染色体に組み込まれないか, もしくは組み込み の効率が悪いため細胞分裂とともに導入遺伝子が希釈され てしまう. 従って血液細胞などの細胞分裂を繰り返す細胞 で長期にわたり遺伝子を発現させる必要がある遺伝子治療 には向かない.レトロウイルスベクターは導入遺伝子が染 色体に組み込まれるためこのような遺伝子治療に向いてい るが, その反面, 遺伝子導入部位がほぼ無作為に選択され るため白血病などの悪性新生物の原因となることが危惧さ れていた. 2002年にフランスの Alain Fisher らのグループ からレトロウイルスベクターを用いた X 連鎖重症複合免 疫不全症 $(\mathrm{X}-\mathrm{SCID})$ の遺伝子治療で著明な治療効果を得 られたことが報告され脚光を浴びた1,2). しかし，その直後 に治療を受けた 10 症例中 2 症例で白血病を発症したことが 衝撃と共に伝えられた ${ }^{3.4)}$. 本稿では最近のレトロウイルス ベクターの進歩, 臨床試験で治療効果の認められた重症複 合免疫不全症の経過, 報告された遺伝子治療関連白血病発 症の機序, これからの研究の方向性などについて述べる.

\section{I 、レトロウイルスベクター}

\section{（1）オンコレトロウイルスベクター}

一般的にレトロウイルスベクターという呼称はオンコウ イルスである moloney murine leukemia virus（MoMLV） などのマウス白血病ウイルスから作られたべクターのこと

日本医科大学 第二生化学

（テ113-8602 東京都文京区千駄木 1-1-5）

Gene Therapy Vsing Retroviral Vectors

Hideki Hanawa, Takashi Shimada

Biochemistry and Molecular Biology Nippon Medical

School

$1-1-5$ Sendagi, Bunkyo-ku, Tokyo 113-8602

TEL : 03-3822-2131

FAX : 03-5814-8156
を指し，以下に述べるレンチウイルスベクターと区別する ためにオンコレトロウイルスベクターと呼ばれることもあ る.

オンコウイルスはウイルスの構造タンパク，プロテアー ゼ，逆転写酵素，インテグラーゼなどになる前駆蛋白をコ ードする gag/pol 遺伝子, エンベロープ糖蛋白をコードす る env 遺伝子を持ち, その両端をエンハンサー, プロモ 一ター, ポリアデニレーションシグナルなどのエレメント が含まれる LTR (long terminal repeat) で挟まれている. この LTRから $\mathrm{gag} / \mathrm{pol}$ 蛋白が翻訳される全長の mRNA と env 蛋白が翻訳されるスプライスされた mRNA が転写 される. 全長の mRNA は同時にウイルスの RNA ゲノム としてウイルス粒子の中に取り込まれる.

遺伝子治療用のベクターでは感染力を保ちつつ自己複製

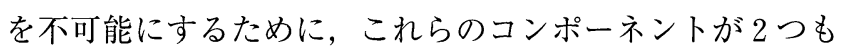
しくは3つに分割されている.すなわちウイルスベクター の gag/pol と env 遺伝子を発現する1つもしくは $2 つ の$ パッケージング・プラスミドとベクターの RNA ゲノムを 産生するためのトランスファーベクター・プラスミドであ る.トランスファーベクターはウイルスの RNA ゲノムか ら $\mathrm{gag} / \mathrm{pol}$ 遺伝子の大部分と env 遺伝子が削除され, そ の代わりに遺伝子治療の目的遺伝子の cDNA が挿入され ている．標的細胞内でこの cDNA はLTRのプロモーター により転写されるが，第 2 の cDNAを転写するために内 部にもう一つのプロモーターを挿入されることもある。

レトロウイルスベクターはこれらのプラスミドを293T 細胞などにトランスフェクションした後にこの細胞の培養 液を回収することにより作ることができるが，この方法で は，（1）ベクターを含む培養液中にプラスミド DNA が 混入するおそれがあること，（2）大量の均一なべクター ストックを作成することが困難なこと，（3）プラスミド DNAの再構成により野生型のウイルスが生成される可能 性があることなどが懸念される。遺伝子治療に用いるレト ロウイルスベクターを作成する場合これらの問題を回避す るため，これらのプラスミドを個別にパーマネント・トラ ンスフェクションもしくはウイルスを用いたトランスダク ションにより $\mathrm{NIH}^{-} 3 \mathrm{~T} 3$ 細胞や 293 細胞などに導入しプロ デューサー細胞株を樹立する方法がとられる（図 2 ). 


\section{MLV (Moloney murine leukemic virus)}
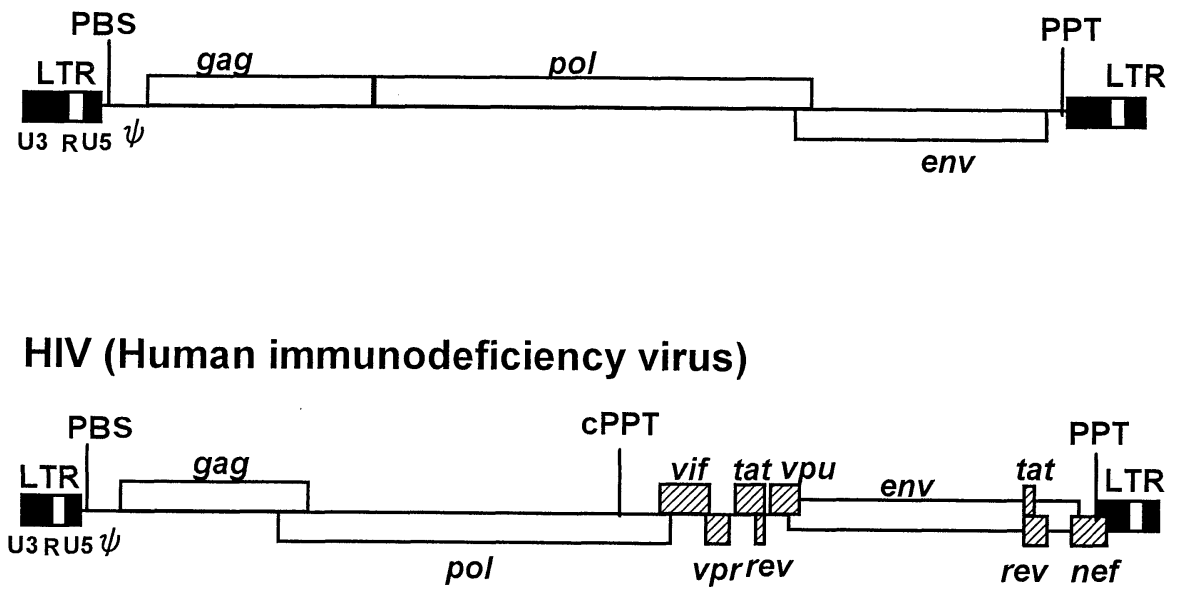

図 1 レトロウイルスの構造

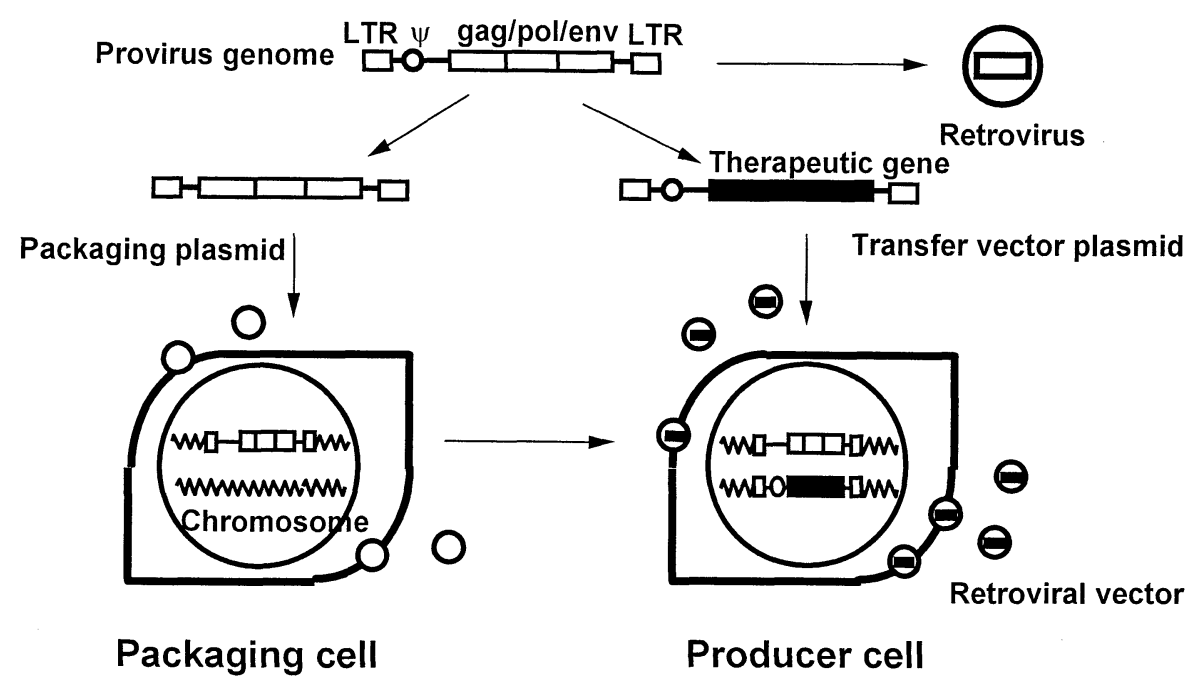

図 2 レトロウイルスベクターの作製

（2）トランスファーベクターの改良

レトロウイルスベクターは遺伝子導入後に染色体に組み 込まれるために恒久的な遺伝子の発現が期待されるが，実 際にはその遺伝子発現は不安定で, 標的細胞内に導入遺伝 子が存在するにもかかわらず発現が認められなくなること もある(サイレンシング)。これは，MoMLVのLTRに

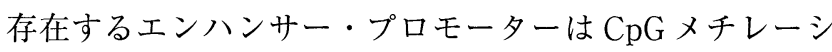
ヨンにより不活化される傾向があること，また，その LTR に negative control region (NCR) が存在すること， 5 'LTR の下流に repressor binding site（RBS）が存在することが 原因であると思われる，RBS は逆転写の開始部位となる primer binding site (PBS) と重なっており，F 9 embryonal carcinoma（EC）細胞や mouse embryonal stem（ES）細 胞，ヒトの幼弱な造血細胞で遺伝子の発現を抑制する。こ
れらを克服すべく改良された MSCV ベクター5，MND ベ クター6)， MFG-S ${ }^{7}$ ベクターなどが作られ，広く使われる ようになってきている.

\section{（3）エンベロープの改良}

古くから使われているオンコレトロウイルスベクターの エンベロープにはマウスだけに感染することができる ecotropic エンベロープとマウスとヒトの両方に感染すること ができる amphotropic エンベロープがある. amphotropic エンベロープでシュードタイプされたレトロウイルスベク ターは初期の大型動物モデルや臨床試験ではあまり思わし い成績が得られなかった。これは標的細胞に amphotropic エンベロープの受容体 (Pit-2) が比較的少ないことが原 因と考えられている ${ }^{8,9)}$. 現在いろいろなウイルスのエンベ 
ロープが比較検討されており, 必ずしも一致した結果は得 られていないが Gibbon ape leukemia virus (GaLV) エン ベロープ (受容体 ; Pit-1 $)^{10}$, Feline endogenous retrovirus（RD114） envelope（受容体 ; sodium-dependent neutral-amino-acid transporter $)^{11}$ などが優れた遺伝子導入効 率を示している ${ }^{12 \sim 14)}$. また，同じエンベロープを使った場 合, マウス由来のプロデューサー細胞よりもヒト由来のプ ロデューサー細胞を使った方がヒヒやヒトの細胞への遺伝 子導入効率は高いようである ${ }^{12)}$.

\section{（4）遺伝子導入条件の改良}

幼弱な造血細胞に遺伝子導入を行う場合プロデューサー 細胞と共培養すると導入効率が上がることは報告されてい た。しかし，レトロネクチン $(\mathrm{CH}-296)$ の出現によりプ ロデューサー細胞と共培養せずとも高い遺伝子導入効率が 得られるようになった。レトロネクチンはウイルスベクタ 一と細胞をそれぞれ結合する部位を持ち，これらを物理的 に近づけることにより遺伝子導入を促進しているものと考 えられている．また，造血細胞がレトロネクチンと結合す ることにより何らかの生存シグナルを伝えていることも考 えられている.

また，最近のリコンビナント技術の進歩により幼弱な造 血細胞を刺激するサイトカインが利用可能となったＩL3, IL-6に比べて SCF, Flt 3-L, TPO などのサイトカイ ンは未分化な造血細胞を刺激すると考えられているが，こ れらのサイトカインの組み合わせにより比較的細胞分裂が ゆっくりであると考えられている造血幹細胞の自己複製能 を損なうことなく細胞分裂させることが可能になってき た。このことにより以前はオンコレトロウイルスベクター が苦手とされていた造血幹細胞への遺伝子導入が可能とな ってきだ2,15).

\section{II . レンチウイルスベクター}

レンチウイルスベクターは human immunodeficiency virus 1 (HIV-1), simian immunodeficiency virus (SIV) などのレンチウイルスから作られたベクターの総称であ る.オンコレトロウイルスベクターはレインテグレーショ ン複合体が染色体 DNA にたどり着くために細胞分裂時の 核膜消失が必要であるため細胞分裂していない細胞に遺伝 子導入することができない。このためレトロウイルスベク ターは細胞分裂しないか, していても非常にゆっくりであ ると思われる造血幹細胞, 神経細胞, 肝細胞, 筋細胞に遺 伝子導入するのには不向きである，一方，レンチウイルス はプレインテグレーション複合体に積極的に核膜を通過す る機能があるのでこういった標的細胞には潜在的に有利で ある。

レンチウイルスベクターの中でもっとも研究が進んでい るのは HIV-1ベクターであるが, HIV-1 は AIDS の原
因ウイルスであるため, 執拗なほど安全面での改良が行わ れてきた. 第二世代 HIV-1 ベクターで行われた vif, vpr, $\mathrm{vpu}$, nef 蛋白の削除 ${ }^{16)}$ ，第三世代 HIV-1 ベクターで行わ れたパッケージング・プラスミドの多分割, tat 蛋白の削 除, SIN (self-inactivating) ベクター化がそれである ${ }^{17,18)}$. 一方で, HIV-1 ベクターの遺伝子導入能力を高める努力 も行われ, cPPT/CTS (central polypurine tract/central termination sequence) のトランスファーベクターへの導 入は HIV- 1 本来の感染能力を回復させべクターの能力を 飛躍的に向上させた。

遺伝子治療を行う場合プロデューサー細胞株を作成する ことが望ましいが, HIV-1 蛋白の細胞毒性のため高力価 なプロデューサー細胞株を作成するのに困難を極めてい た. 最近オンコレトロウイルスベクターを用いて HIV-1 ベクターのパッケージング・コンポーネントを細胞株に導 入することにより高力価なパッケージング細胞株が作られ たことが報告された ${ }^{19}$. しかしながら依然として SIN べク ターを用いて安定した高力価なプロデューサー細胞株を作 ることは困難なようである.

論理的にオンコレトロウイルスベクターよりも遺伝子導 入効率が優れているが，オンコレトロウイルスベクターの 改良, 遺伝子導入技術の進歩によりアドバンテージが見え にくくなっている.サルなどの大型動物の造血幹細胞の細 胞分裂などの動態はヒトに近く, 臨床試験を予測する上で 有用なデー夕が得られると信じられているが，最近の HIV-1 ベクターによるサルの造血幹細胞へのマーキングスタディ ではあまり良好な結果が得られていないことも HIV-1べ クターには逆風となっている ${ }^{20,21)}$. しかし，これはレンチ ウイルスと宿主動物の種異性に起因する結果であり, 最近 の我々の最近の研究ではSIV ベクターを用いれば Rhesus Monkey モデルでかなり高い遺伝子導入効率と安定した遺 伝子発現が得られることがわかってきた. 今後，HIV-1 ベクターなどのレンチウイルスベクターは鎌状赤血球症の 遺伝子治療のように複雑な遺伝子発現カセットを高効率に 遺伝子導入することが必要な領域で進化を続けていくもの と思われる。

\section{III.レトロウイルスベクターによる先天性 重症複合免疫不全症の遺伝子治療}

\section{（1）アデノシンデアミナーゼ欠損重症複合免疫不全症（ADA- SCID)}

ADA-SCID はアデノシンデアミナーゼ遺伝子異常によ る先天性重症免疫不全症である．標的細胞としては造血幹 細胞が理想的であったが当時の技術としては十分な遺伝子 導入が不可能であったため, 1990年からアメリカの NIH のグループが成熟 $\mathrm{T}$ 細胞を標的細胞とした遺伝子治療を 2 人の患者を対象に開始した ${ }^{22}$. この疾患では本来なら末 梢血液にリンパ球がほとんど存在しないが，このころから 


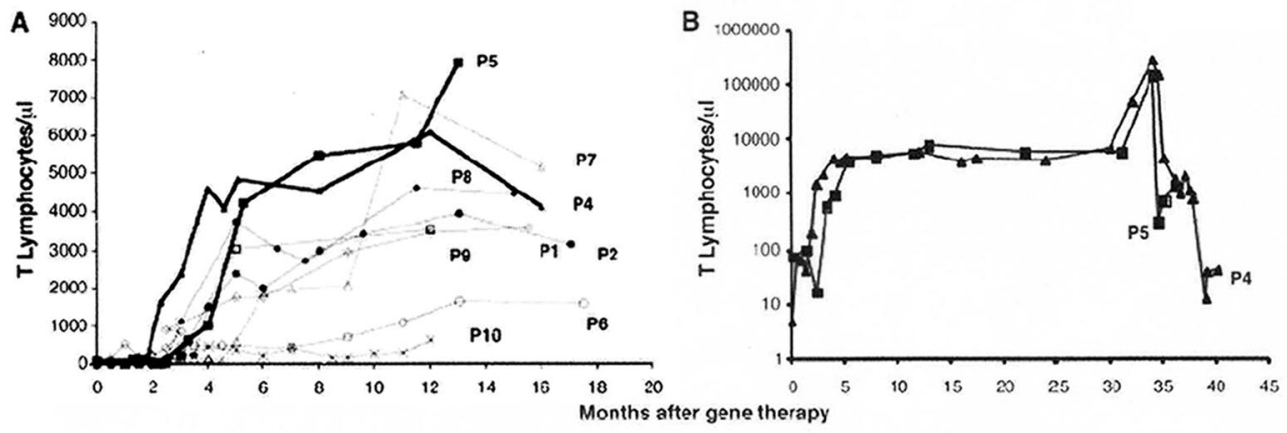

図 3 遗伝子治療後の X-SCID 患者の末梢血. T 細胞数の経過

(Hacein-Bey-Abina S. et al, Science $302 ： 415-419$, 2003より拔粋)

開始された䣼素補充療法（PEG-ADA）が奏功し T 細胞 を回収することが可能になっていた。これらの患者から回 収したT細胞に生体外で ADA 遗伝子発現レトロウイル スベクターを用いて遺伝子導入し患者の体に返還するとい う治療を 2 年間にわたり繰り返した。遺伝子治療中も酲素 補充潦法を続けていたため遗伝子治療単独の治療効果の評 価は難しいが，治療開始後から現在までの 10 年以上の期間 末梢血中に遗伝子導入された T細胞が存在し続けてお り，また特に有害事像は発生していない，午の後同様の遺 伝子治療がイタリアおよび日本で行われほほ同様の結果を 得ている23.24.

骨髄造血幹細胞を標的とした ADA-SCID の遗伝子治療 は1992年からイタリアのグループで開始され²3)，続いてフ ランス，イギリスでも開始された．1993年からはNIHの グループが膀带卹造血幹紐胞を標的とした遺伝子治療を開 始した25. 現在まで有害事象は報告されていないが，いず れも遺伝子導入効率は低く長期にわたる治療効果を得るに は至っていない。

2002年にイタリアのグループから最新技術を用いた遺伝 子治療で治療效果を得たとの報告がなされた 䯣から採取した CD34陽性細胞を SCF, FLT 3-L, Thrombopoietin-m, IL-3 で刺激し，レトロネクチンでコートさ れたフラスコ内で遗伝子導入を行った，免疫システムの完 全なあるいは部分的な再櫐棨を㤎め感染症もまた再発性の 感染症も消失した。この臨床試験が成功した理由には改善 された遺伝子導入技術に加え，骨㕼移植に際してブスルフ アンによる非骨䯣破壊的前処置を行ったこと, 対象患者が 事情により酵素補充療法を受けることができなかったため 遺伝子導入された細胞が選択的に增殖できたことなどがあ げられる。

\section{（2） X 連鎖重症複合免疫不全症 (X-SCID)}

X-SCID は IL-2, IL-4, IL-7, IL-9, IL-15，およ びIL-21に共通する $\gamma$ 鎖（common $\gamma$ chain； $\gamma$ c）の遺伝子. 異常により発症する。これらのレセプターからの刺激は $\mathrm{T}$
細胞， B 紐胞， NK 細胞などの分化增殖に重要である，そ のため患者の末梢血には T 細胞, NK 細胞は認められず,

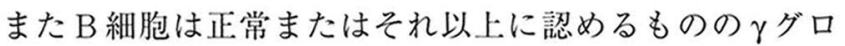
ブリンは涊めない。このため感染症を繰り返しその大部分 は生後 1 年以内に死に至る. 治療法は骨镂移植である. 骨 随移植後の生存率は HLA 適合ドナーが見つかった場合で 90\%，HLA ハプロ適合の場合70\%-78\%といわれている. しかし, 必ずしもドナーが見つかるわけではなく, またド ナーが見つかり骨䯆移植が成功してもGVHD の危険は常 につきまとい，しかもB 細胞の機能が回復することはま れで免疫グロブリン製剤の定期的輸注が必要である.

骨䯣移植の有望な代替療法として遺伝子治療が考えられ た.この疾患も ADA-SCID と同様に単一遗伝子の異常に よる疾患なので, $\gamma c$ 遗伝子発現レトロウイルスベクター を用いて造血幹細胞に遗伝子導入すればよいと考えられ る.しかも, $\gamma c$ が関与しているサイトカインレセプター は直接リンパ球の増殖に関与しているので, たとえ遺伝子 導入効率が悪くても遺伝子導入により修正されたリンパ球 が選択的に增幅されていくと考えられ，遗伝子治療に好都 合である。

ヒトでの臨床試験は1999年にフランスの Alain Fisher ら のグループで開始された ${ }^{1.2)}$ 。まず骨䯣細胞を採取し CD 34 陽性細胞に純化した後にサイトカイン (SCF, FLT 3-L, MGDF， IL-3）で造血幹細胞を刺激し，次にレトロネク チンでコートした滅菌バッグ中でベクターを含む培荃液で 培養し遺伝子導入した。ベクターを含む培養液は24時間お きに新鮮なものと交換され, CD 34 陽性細胞は計 3 回べク ターに暴露されている. その後, CD34陽性細胞を回収し 患者に前処置なしで投与した.

総数で 10 人の患者に遺伝子治療を行い，うち 9 人で末梢 血注に T 細胞, NK 細胞, $\gamma$ グロブリンなどの出現を認め た (図 3 ). 残りの一人は $\mathrm{B}$ 細胞, 単球の一部に導入され た遺伝子を認めたが，T䋛胞は出現しなかった。この患者

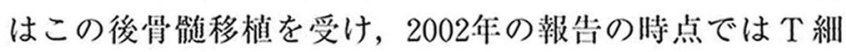
胞の增加傾向を認めたとのことである．また，2002年の報 
告の段階で治療効果を認めた 4 人中 1 人では低 $\gamma$ グロブリ ン血槳が持続し，また別の 1 人では予防接種に対する免疫 応答を認めなかったとのことである. 最終的に治療効果の あった 9 人中，この免疫の再構築が不十分であった 2 人が T 細胞性白血病を発症している ${ }^{4)}$.

Patient 4 は遺伝子治療後約 30 ヶ 月で $\gamma \delta \mathrm{T}$ 細胞の増加を 認め, 同時期に感染していた水痘によるものと考えられて いたが，T 細胞数はそのまま指数的に増加した。遺伝子治 療後約 34 ケ月の時点で脾腫, 骨髄浸潤を認め, 未梢血細胞 の細胞膜表面抗原は成熟 $\mathrm{T}$ 細胞型，イムノスコープ分析

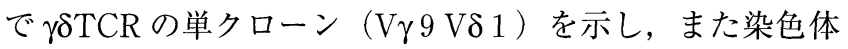
異常 $(\operatorname{der}(13) \mathrm{t}(6 ； 13))$ も認めた。これらにより T 細胞 急性白血病と診断され化学療法を施行. 遺伝子治療後40 个 月に非血縁 HLA 適合ドナーから骨髄移植を受けている. 微小残存病変は残っているが現在の状態は良好とのことで ある。

Patient 5 は遺伝子治療後 34 ケ月に貧血を伴う白血球数 の急上昇, 脾腫, 縦隔の拡大を認めた. 末梢血細胞の細胞 膜表面抗原は同様に成熟 $\mathrm{T}$ 細胞型で，イムノスコープ分 析で $\alpha \beta T C R$ のリゴクローン（V $\beta 1, V \beta 2, V \beta 23)$ を 示していた. また, SIL-TAL 1 転座, トリソミー10の染 色体異常も認めた. T 細胞急性白血病と診断し, 化学療法 を施行したところ臨床的に寛解に至っており現在のところ 状態は良好とのことである.

遺伝子導入部位を Linear Amplification Mediated PCR (LAM-PCR) 法で解析したところ Patient 4 では原癌遺 伝子 LMO 2 (LIM domain only-2 ) の転写開始部位下流 約 $2 \mathrm{~kb}$ に遺伝子の方向と逆向きに挿入されており, $\mathrm{Pa}$ tient 5 では同じ遺伝子 (LMO 2) の転写開始部位上流約 $3 \mathrm{~kb}$ に遺伝子の方向と同じ向きに挿入されていた。さら に詳しく分析したところ，これらの腫瘍細胞ではどちらも 正常細胞より明らかに高いレベルの LMO 2 遺伝子発現を みとめ, それも，2つあるLMO 2 のアレルのうちべク夕 一が挿入されている方のみが活性化していることが証明さ れた. ベクターの $\gamma c$ 遺伝子の異常高発現や, 制御不可能 で持続的な下流のシグナル伝達系の活性化, 逆転写時の遺 伝子変異によるシグナル伝達能の上昇 (Gain-of-function mutations）なども白血病化の一因として危惧されたが,

これらの腫瘍細胞でそういった異常はないことが報告され ている4.

総合的に判断すると, 今回の遺伝子治療関連白血病には ベクターの挿入によるLMO 2 遺伝子の活性化が共通した 根本的原因として存在し, 元々ある発癌の先天的素因に加 えウイルス感染, 染色体異常の蓄積などが重なり発症した ものと思われる. 今回の 2 症例ではどちらも LMO 2 遺伝 子が原因で白血病を発症しているが，これはLMO 2 遺伝 子が物理的にベクターの挿入しやすい“ホット・スポッ ト”である可能性，もしくは遺伝子導入はランダムである
がLMO 2 遺伝子が活性化したクローンがほかのクローン に比べて増殖しやすいなどの可能性がある.

\section{IV. 今後の研究の方向性}

白血病の発症にはいろいろな因子が重なっているが, 根 本的には原癌遺伝子 LMO 2 の活性化があり, 当面はこれ をいかに回避するかいうことになるであろう.

\section{（1）オンコレトロウイルスベクターの改良}

\section{i ) SIN ベクター}

LOM 2 の活性化がベクターの挿入によるものであるか ら，まず考えられるのはベクターのエンハンサーを取り除 き自己不活型（self-inactivating；SIN）ベクターにするこ とである，以前からオンコレトロウイルスベクターを SIN ベクターにすることは考えられているが, SIN ベクターの 問題点は力価の高いプロデューサー細胞株ができないとい うことにある.この理由はわかっていない. 安定したプロ デューサー細胞を作らずプラスミドのトランスフェクショ ンによりベクターを作製する方法には前述した様ないろい ろな問題があるのでそれを克服する必要がある。

\section{ii）インシュレーター}

オンコレトロウイルスのエンハンサーを取り除かないま でもエンハンサーの絶縁体（インシュレーター）を使う方 法も考えられる．インシュレーターはいくつか報告されて いるがその中でよく研究されているのは Chicken $\beta$-globin hypersensitivity site 4 (cHS4) である ${ }^{26)}$. 当初，このイ ンシュレーターはベクターの発現を安定させるために開発 された。レトロウイルスベクターからの遺伝子発現の強度 はクローンによりまちまちであり，おそらくこれはべク夕 一が挿入された周囲の遺伝子のエンハンサー・サイレンサ 一の影響によるものと考えられている. Emery らはイン シュレーターを用いて安定した遺伝子発現を得ようと考え た ${ }^{277}$. 周囲からの影響を遮断するためには発現カセットの 上流と下流にインシュレーターを挿入する必要があるが, レトロウイルスでは塩基配列の反復があると遺伝子再構成 を起こしてしまうことが知られており，ベクター内部の上 流と下流に同じエレメントを挿入するとベクターがうまく 作れなくなってしまう。彼らはこれを回避するためインシ ユレーターを 3 'LTRに挿入することを考えた。こうする とベクターの RNA ゲノム上にはインシュレーターは一つ しか存在しないが，逆転写時にこれがもう一方の LTRに コピーされるため最終的に目的の形のプロウイルスが完成 するわけである (double copy vector)。この方法の問題は ベクターの力価が有意に下がってしまい感染力も低下して しまうこと，また，通常のオンコレトロウイルスベクター で使った場合 3 'LTR に存在するエンハンサーをブロック できないことにあると思われる．後者はSIN ベクターと することで回避できるが，SINベクター自体にも問題は残 
されている。

\section{（2）治療開始年槅の制限}

今回白血病を発症した症例はそれぞれ生後 1 ケ月， 3 ケ 月に遺伝子治療を受けているため, 白血病の発症が何らか の理由で治療時の月例と関連している可能性がある. 今後 遺伝子治療を再開するに当たって考慮する必要があると思 われる。

\section{（3）レンチウイルスベクターの使用}

オンコレトロウイルスベクターもレンチウイルスベクタ 一も活性化している遺伝子に組み込まれる傾向があること が知られている. LMO 2 もおそらく遺伝子導入時に活性 化していたものと思われる，オンコウイルスはレンチウイ ルスに比べ転写開始部位の近くに挿入されやすいことが報 告されている ${ }^{28)}$. したがってレンチウイルスベクターを使 用することによりべクターのエンハンサーにより原癌遺伝 子を活性化する確立を低くできる可能性がある，また，遺 伝子導入時に幼弱な造血細胞を刺激するサイトカインを使 用すれば，細胞を分裂増殖させる遺伝子を活性化すると思 われるが，これは原癌遺伝子をレトロウイルスベクターに さらされやすくしている可能性を意味する. サイトカイン の使用はオンコレトロウイルスベクターにとっては必須で あるが，レンチウイルスベクターにとっては必ずしも必須 ではない.したがって，サイトカインを用いずにレンチウ イルスベクターを用いて遺伝子導入すれば原癌遺伝子を活 性化する確立をさらに低くすることができるかもしれな い.

\section{（4）安全性のアッセイ系の確立}

これが何よりも重要で, かつ達成困難な点かもしれな い.いろいろと改善すべき点，アイデイアはあるが，再度 臨床試験を行うためには十分納得するための高い品質のデ ータが必要である．どのように巧みに実験系を組んで証明 していくかがこれからの課題である.

\section{おわりに}

X-SCID の今回報告された遺伝子治療では 10 症例中 2 症 例で白血病を発症しているが，10症例中 9 症例で明らかな 治療効果を認めた点は遺伝子治療の潜在的有用性を実証し たものとして評価するべきである。2003年12月に開催され た第45回 American Society of Hematology（ASH）学会 でCavazzana-Calvo らから，同遺伝子治療を骨髄移植に 対するサルベージとして再開することが関係機関に了承さ れたことが報告された。レトロウイルスベクターは遺伝性 疾患の治療用としては理論的にも実際的にも現時点では最 も優れたべクターであることは間違いない，残念ながら 我々は未だこのべクターを使いこなせていないが，今後の
基礎研究の積み重ねで, 更に安全で有用なべクターとして 改造していくことは可能であると確信している.

\section{参考文献}

1) Cavazzana-Calvo $\mathrm{M}$ et al : Gene therapy of human severe combined immunodeficiency (SCID) - X 1 Disease. Science 288：669-672, 2000

2 ) Hacein-Bey-Abina $\mathrm{S}$ et al : Sustained correction of Xlinked severe combined immunodeficiency by ex vivo gene therapy. N Engl J Med. 346 : 1185-1193, 2002

3 ) Hacein-Bey-Abina $\mathrm{S}$ et al : A serious adverse event after successful gene therapy for X-linked severe combined immunodeficiency. N Engl J Med. 348 : 255256, 2003

4) Hacein-Bey-Abina S et al : LMO 2 -associated clonal $\mathrm{T}$ cell proliferation in two patients after gene therapy for SCID-X 1. Science 302 : 415-419, 2003

5 ) Hawley RG et al : Versatile retroviral vectors for potential use in gene therapy. Gene Ther. $1: 136^{-138,}$ 1994

6 ) Halene $\mathrm{S}$ et al : Improved expression in hematopoietic and lymphoid cells in mice after transplantation of bone marrow transduced with a modified retroviral vector. Blood $94: 3349-3357,1999$

7 ) Riviere I et al : Effects of retroviral vector design on expression of human adenosine deaminase in murine bone marrow transplant recipients engrafted with genetically modified cells. Proc Natl Acad Sci U S A. 92 : 6733-6737, 1995

8 ) Kavanaugh MP et al : Cell-surface receptors for gibbon ape leukemia virus and amphotropic murine retrovirus are inducible sodium-dependent phosphate symporters. Proc Natl Acad Sci U S A. 91 : 7071-7075, 1994

9 ) von Kalle $\mathrm{C}$ et al : Increased gene transfer into human hematopoietic progenitor cells by extended in $v i$ tro exposure to a pseudotyped retroviral vector. Blood 84:2890-2897, 1994

10) Miller $\mathrm{AD}$ et al : Construction and properties of retrovirus packaging cells based on gibbon ape leukemia virus. J Virol. 65 : 2220-2224, 1991

11) Cosset FL et al : High-titer packaging cells producing recombinant retroviruses resistant to human serum. J Virol. 69 : 7430-7436, 1995

12) Horn $\mathrm{PA}$ et al : Highly efficient gene transfer into baboon marrow repopulating cells using GALV-pseudotype oncoretroviral vectors produced by human packaging cells. Blood 100 : 3960-3967, 2002

13) Brenner $\mathrm{S}$ et al : Concentrated RD114-pseudotyped MFGS-gp91phox vector achieves high levels of functional correction of the chronic granulomatous disease oxidase defect in NOD/SCID/beta-microglobulin-/repopulating mobilized human peripheral blood CD34 + cells. Blood 102 : 2789-2797, 2003

14) Hu J et al : Direct comparison of RD114-pseudotyped versus amphotropic-pseudotyped retroviral vectors for transduction of rhesus macaque long-term repopulating cells. Mol Ther. $8: 611-617,2003$

15) Aiuti A et al: Correction of ADA-SCID by stem cell 
gene therapy combined with nonmyeloablative conditioning. Science 296 : 2410-2413, 2002

16) Zufferey $R$ et al : Multiply attenuated lentiviral vector achieves efficient gene delivery in vivo. Nat Biotechnol. 15:871-875, 1997

17) Dull $\mathrm{T}$ et al : A third-generation lentivirus vector with a conditional packaging system. J Virol. 72 : 84638471, 1998

18) Zufferey $\mathrm{R}$ et al : Self-inactivating lentivirus vector for safe and efficient in vivo gene delivery. J Virol. 72 : 9873-9880, 1998

19) Ikeda $Y$ et al : Continuous high-titer HIV-1 vector production. Nat Biotechnol. 21 : 569-572, 2003

20) An DS et al: Lentivirus vector-mediated hematopoietic stem cell gene transfer of common gammachain cytokine receptor in rhesus macaques. J Virol. 75:3547-3555, 2001

21) Donahue RE et al : Fibronectin fragment CH-296 inhibits apoptosis and enhances ex vivo gene transfer by murine retrovirus and human lentivirus vectors independent of viral tropism in nonhuman primate CD $34+$ cells. Mol Ther. 3 : 359-367, 2001

22) Blaese RM et al : T lymphocyte-directed gene ther- apy for ADA-SCID : initial trial results after 4 years. Science. $270: 475-480,1995$

23) Bordignon $\mathrm{C}$ et al : Gene therapy in peripheral blood lymphocytes and bone marrow for ADA-immunodeficient patients. Science. 270 : 470-475, 1995

24) Onodera $M$ et al: Successful peripheral T-lymphocyte-directed gene transfer for a patient with severe combined immune deficiency caused by adenosine deaminase deficiency. Blood. 91 : 30-36, 1998

25) Kohn DB : Engraftment of gene-modified umbilical cord blood cells in neonates with adenosine deaminase deficiency. Nat Med. 1 : 1017-1023, 1995

26) Chung JH : A 5 ' element of the chicken beta-globin domain serves as an insulator in human erythroid cells and protects against position effect in Drosophila. Cell. 74 : 505-514, 1993

27) Emery DW : A chromatin insulator protects retrovirus vectors from chromosomal position effects. Proc Natl Acad Sci U S A. 97 : 9150-9155, 2000

28) $\mathrm{Wu} \mathrm{X}$ et al : Transcription start regions in the human genome are favored targets for MLV integration. Science 300 : 1749-1751, 2003 